\title{
Aplikasi Pengolahan Citra Elektrokardiograf dan Jaringan Syaraf Tiruan untuk Identifikasi Penyakit Jantung Koroner
}

\author{
Endarko* dan Farid Afandy \\ Lab. Elektronika dan Instrumentasi, Jurusan Fisika, FMIPA, \\ Institut Teknologi Sepuluh Nopember, Kampus ITS Sukolilo, Surabaya 60111 \\ Mohammad Soetomo \\ IRNA Medik, Poli Jantung RSUD dr. Soetomo - Surabaya
}

\begin{abstract}
Intisari
Telah dirancang perangkat lunak untuk identifikasi penyakit jantung koroner melalui pengenalan citra EKG. Perangkat lunak ini menggunakan aplikasi pengolahan citra dan jaringan syaraf tiruan. Pengolahan citra digunakan untuk mengolah citra EKG hingga diperoleh seratus data numerik sebagai inputan jaringan syaraf tiruan. Operasi pengolahan citra yang digunakan adalah operasi titik (operasi pointwise) berdasarkan intensitas piksel, di mana citra discan secara vertikal dan horisontal, dideteksi intensitasnya dan dipetakan ke nilai 1 untuk grafik dan 0 untuk latar belakang grafik. Sedangkan jaringan syaraf tiruannya dibangun berdasarkan metode backpropagation sederhana. Dengan menggunakan fungsi aktivasi sigmoid bipolar dan parameter training: learning rate $=0.1$, maksimum epoch $=5000$, dan target error $=0.01$ diperoleh bahwa konfigurasi optimal jaringan adalah 100-10-1. Setelah dilakukan uji program, diperoleh hasil bahwa jaringan syaraf tiruan mampu mengidentifikasi kondisi jantung normal, iskemia depresi ST, iskemia inversi T, injuri elevasi T, dan nekrosis Q patologis.
\end{abstract}

KATA KUNCI: penyakit jantung koroner, citra EKG, pengolahan citra, jaringan syaraf tiruan, backpropagation

\section{PENDAHULUAN}

Jaringan syaraf tiruan (JST) dapat digunakan untuk menyelesaikan banyak permasalahan. Misalnya untuk mengenali tulisan tangan seseorang, untuk mengenali suara, wajah, atau untuk memprediksi bursa saham dan laba perusahaan di masa mendatang. Bahkan di bidang kedokteran dapat digunakan untuk mengenali penyakit jantung seseorang melalui pembacaan citra elektrokardiografi (EKG) $[1,2]$. Kemampuan JST dalam mengenali pola EKG akan sangat membantu dalam perkembangan kedokteran khususnya bidang kardiologi. Kita mengetahui bahwa jantung merupakan salah satu organ tubuh yang paling vital yang berfungsi mengatur peredaran darah ke seluruh bagian tubuh. Dan penyakit jantung khususnya penyakit jantung koroner (PJK) merupakan penyakit yang sangat berbahaya penyebab kematian nomor satu di Indonesia dan di negara-negara lain di dunia. Hal ini sesuai dengan hasil survei Rumah Tangga Departemen Kesehatan tahun 1996 yang menyatakan bahwa PJK menduduki peringkat pertama sebagai penyebab kematian di Indonesia sedangkan menurut SEAMIC Healt Statistic 2000 menyatakan bahwa penyakit serbiovaskuler seperti jantung koroner dan stroke menduduki peringkat kedua penyebab kematian tertinggi di dunia $[3,4]$. Penelitian ini bertujuan untuk membuat perangkat lunak dengan menggunakan pengolahan citra [5, 6] dan

*E-MAIL: endarko@physics.its.ac.id jaringan syaraf tiruan untuk mengidentifikasi penyakit jantung koroner.

\section{TINJAUAN PUSTAKA}

\section{A. Elektrokardiografi (EKG)}

Elektrokardiografi yang disingkat dengan EKG merupakan alat diagnosis penyakit jantung manusia. EKG memiliki alektroda-elektroda yang ditempatkan pada bagian tubuh tertentu untuk merekam potensial listrik yang dibangkitkan oleh jantung. Peletakan elektroda disebut sandapan (lead) EKG yang dapat dilihat pada Gambar 1. Ada dua macam sandapan EKG yaitu [7, 8]:

1. Sandapan Prekordial

Sandapan ini terdiri dari enam titik (V1, V2, V3, V4, V5, V6) yang diletakkan di sekitar dinding anterior dada.

2. Sandapan Ekstrimitas yang terdiri dari tiga sandapan, yaitu :

- Sandapan I. Dalam perekaman sadapan ekstrimitas I, ujung negatif EKG dihubungkan dengan lengan kanan (LKa) dan ujung positif dihubungkan dengan lengan kiri (LKi).

- Sandapan II. Dalam perekaman sandapan ekstrimitas II, ujung negatif EKG dihubungkan dengan 

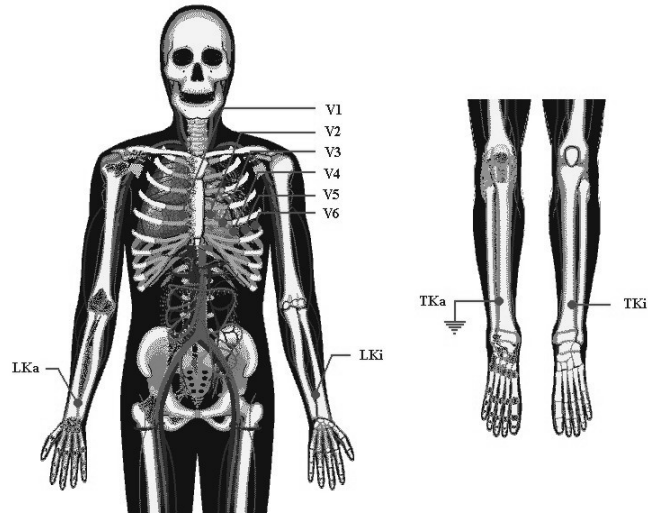

Gambar 1: Letak elektroda-elektroda ekstrimitas dan prekordial[1]

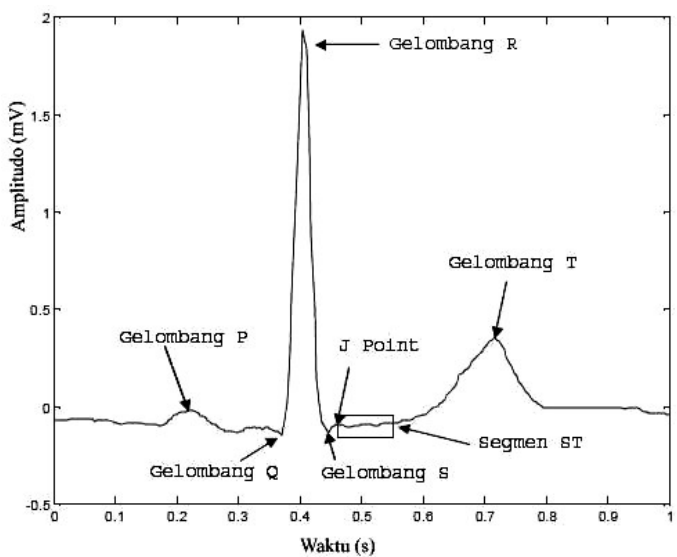

Gambar 2: Elektrokardiogram untuk satu kali denyut jantung [9]

lengan kanan (LKa) dan ujung positif dihubungkan dengan tungkai kiri (TKi).

- Sandapan III. Dalam perekaman sandapan ekstrimitas III, ujung negatif EKG dihubungkan dengan lengan kiri (LKi) dan ujung positif dihubungkan dengan tungkai kiri (TKi).

Hasil perekaman EKG disebut elektrokardiogram yang berupa grafik hubungan antara waktu dengan beda potensial yang ditimbulkan oleh aktivitas jantung seperti Gambar 2.

Elektrokardiogram ada yang ditampilkan pada layar monitor dan ada pula yang langsung ditulis dengan pena pada selember kertas yang bergerak (disebut perekam pena). Pena biasanya berupa pipa halus yang salah satu ujungnya dihubungkan dengan suatu bak tinta dan ujung perekamnya dihubungkan dengan sistem elektromagnetik yang mampu menggerakkan pena bolak-balik dengan kecepatan tinggi [7].

\section{B. Jaringan Syaraf Tiruan (JST)}

Elektrokardiogram hanya bisa dibaca oleh orang-orang tertentu misalnya dokter jantung atau operator EKG. Bagi masyarakat awam, elektrokardiogram hanyalah sebuah kertas

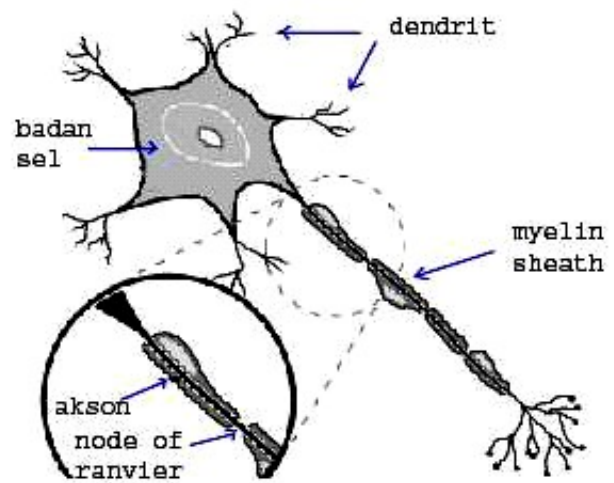

Gambar 3: Sel syaraf manusia [1]

milimeter yang berisi garis-garis yang tersusun secara kontinyu dan tidak teratur. Oleh karena itu diperlukan EKG yang dilengkapi dengan sistem yang dapat menterjemahkan maksud dari elektrokardiogram. Sehingga tidak diperlukan pengetahuan khusus untuk membaca elektrokardiogram. Sistem yang demikian dapat dilakukan oleh jaringan syaraf tiruan dengan meniru kemampuan dokter jantung dalam menganalisis elektrokardiogram.

Jaringan Syaraf Tiruan dibangun dengan mengadopsi kemampuan dan struktur otak manusia sehingga komponenkomponen penyusun Jaringan Syaraf Tiruan mirip dengan komponen-komponen penyusun otak manusia [10-12].

Otak manusia terdiri dari sel-sel syaraf (neuron) yang sangat banyak jumlahnya dan saling berinteraksi satu sama lain untuk memproses informasi yang berupa impuls. Gambar 3 merepresentasikan satu neuron yang terdiri dari :

1. Badan sel yang merupakan tempat inti sel.

2. Inti sel yang mengatur seluruh kegiatan neuron termasuk mengatur proses penyampaian informasi.

3. Dendrit yang merupakan serabut pendek yang bercabang-cabang dan berfungsi sebagai unit masukan yang menerima impuls dari neuron lain untuk dikirim ke badan sel.

4. Akson (Neurit) yang merupakan serabut panjang dan umumnya tidak bercabang berfungsi sebagai unit keluaran yang menerima impuls dari badan sel dan mengirimmnya ke neuron lain.

\section{Citra Digital}

Jaringan Sayaf Tiruan yang akan dirancang memerlukan inputan citra. Oleh karena itu pengetahuan tentang citra digital sangat diperlukan, terutama pada proses pengolahannya sehingga citra mudah diinterpretasikan.

Citra digital direpresentasikan dalam bentuk matriks berukuran $\mathrm{H}$ x W $(\mathrm{H}=$ tinggi, $\mathrm{W}=$ lebar $)$. Bila citra memiliki 256 derajat keabuan, maka nilai setiap elemen matriks adalah 


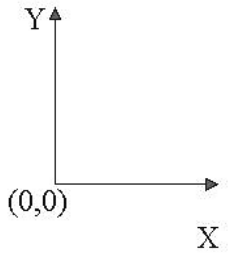

a

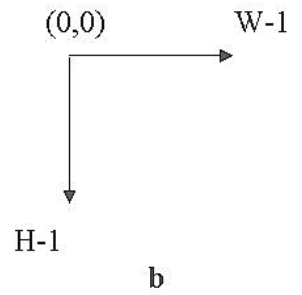

b

Gambar 4: Sistem kordinat: a) Kartesius, b) Citra digital

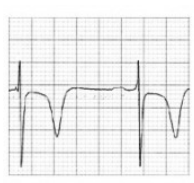

Citra EKG
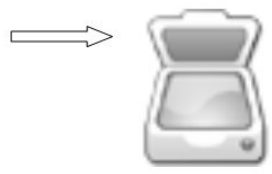

Scanner

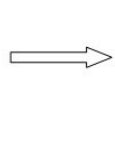

Gambar 5: Diagram blok perangkat keras

bilangan bulat dalam selang 0 sampai 255. Sistem koordinat citra digital berbeda dengan sistem koordinat kartesius. Pusat koordinat citra digital terletak pada sudut kiri atas, sedangkan pada koordinat kartesius terletak pada sudut kiri bawah [13]. Setiap citra memiliki karakteristik tertentu, antara lain: ukuran citra, resolusi, dan format nilainya. Citra digital berbentuk persegi panjang yang tersusun dari elemen-elemen gambar yang disebut piksel $[5,6]$. Semakin banyak piksel citra, semakin baik kwalitas citra tersebut. Selain piksel, ukuran citra juga dapat dinyatakan dengan satuan panjang, misalnya milimeter atau inchi. Satuan panjang citra berhubungan dengan resolusi yang merupakan ukuran banyaknya titik untuk setiap satuan panjang. Semakin besar resolusi, semakin banyak titik yang terkandung dalam citra dengan ukuran fisik yang sama. Berikutnya adalah format citra digital yang terdiri dari banyak ragamnya. Tiga format citra yang paling umum adalah bitmap (BMP), Joint Photographic Experts Group (JPEG), dan Graphic Interchange Format (GIF) [5, 13].

\section{METODOLOGI PENELITIAN}

\section{A. Perangkat Keras Pengolah Citra}

Untuk memproses citra EKG diperlukan empat komponen, yaitu scanner, komputer, piranti tampilan, dan piranti penyimpanan. Mula-mula citra EKG diubah ke bentuk digital dengan menggunakan scanner. Hasil scanner merupakan input untuk komputer yang dapat ditampilkan pada monitor dan disimpan pada hardisk yang merupakan media penyimpan data. Di dalam komputer terjadi proses pengolahan citra yang menghasilkan data numerik sebagai inputan JST.

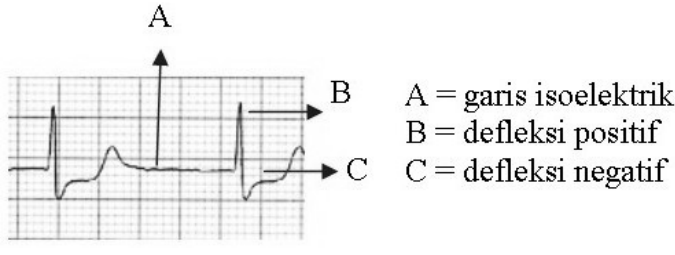

Gambar 6: Contoh citra EKG

\section{B. Perancangan dan Pembuatan Program Pengolah Citra EKG}

Secara garis besar, di dalam program pengolah citra EKG terjadi proses berikut $[5,6]$ :

1. Menghilangkan noise yang terdapat pada citra (Preprocessing).

2. Segmentasi

Proses ini merupakan tahapan pemisahan grafik dengan latar belakangnya. Dengan meggunakan operasi titik, masing-masing piksel di dalam citra discan, dideteksi intensitasnya dan dipetakan ke nilai 1 dan 0 berdasarkan nilai threshold yang ditentukan secara otomatis oleh program, yaitu dilakukan scanning secara vertikal dan horisontal. Bila pada proses scanning ditemukan piksel dengan perubahan intensitas warna yang mendadak dan memiliki nilai intensitas yang lebih kecil dibandingkan lingkungannya, maka piksel tersebut dianggap sebagai objek dan diberi nilai 1 , piksel yang lainnya diberi nilai 0 .

\section{Seleksi ciri}

Tahap ini adalah tahap memilih data untuk dijadikan input program JST. Aturan pengambilan data input JST adalah :

- Menentukan garis isoelektrik yang merupakan garis rekaman mendatar. Garis isoelektrik sebagai acuan dan memiliki nilai nol, defleksi yang arahnya ke atas bernilai positif dan defleksi ke bawah bernilai negatif.

- Menentukan nilai maksimum grafik, yaitu: titik yang memiliki defleksi terbesar, bisa defleksi positif atau defleksi negatif.

- Mengambil seratus data dimulai nilai maksimum grafik

\section{Diagram alir proses training JST}

Diagram alir proses training JST dan diagram alir program utama ditunjukkan pada Gambar 7 dan Gambar 8 . 


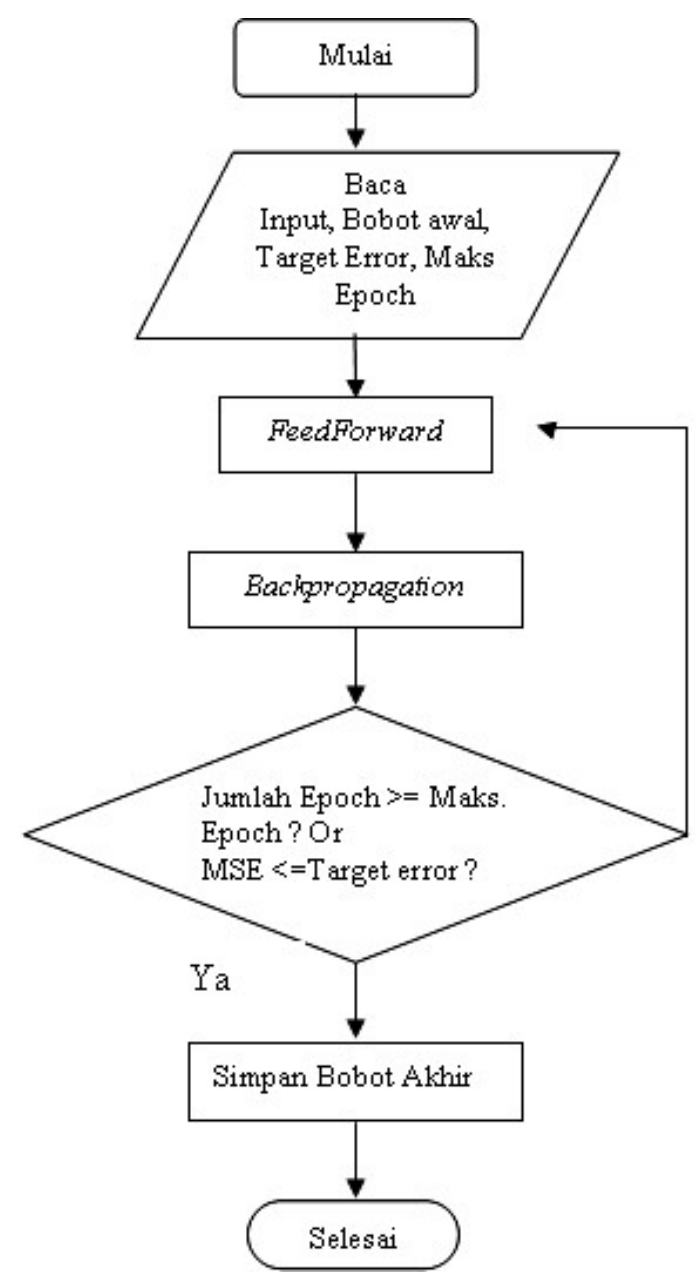

Gambar 7: Diagram alir proses training JST

\section{HASIL DAN PEMBAHASAN}

\section{A. Pengolahan Citra EKG}

Program pengolah citra EKG dibuat dengan menggunakan bahasa $\mathrm{C}++$ toolkit $\mathrm{Qt}$, karena $\mathrm{C}++$ mempunyai penanganan tipe pointer yang lebih dinamis dari pada bahasa pascal. Program pengolah citra digunakan untuk memproses citra EKG hingga diperoleh output berupa data numerik yang berjumlah seratus. Data ini digunakan sebagai inputan untuk program JST. Tampilan program pengolah citra dapat dilihat pada Gambar 9.

Dengan mengklik tombol Apply, secara otomatis program akan mengambil seratus data yang diinginkan. Data ini disimpan dalam file text untuk diakses oleh program JST. Data ini juga dapat diakses oleh program WordPad, Microsoft Word atau program pengakses text lainnya.

Seratus data yang diperoleh dari citra ditunjukkan pada Gambar 10.

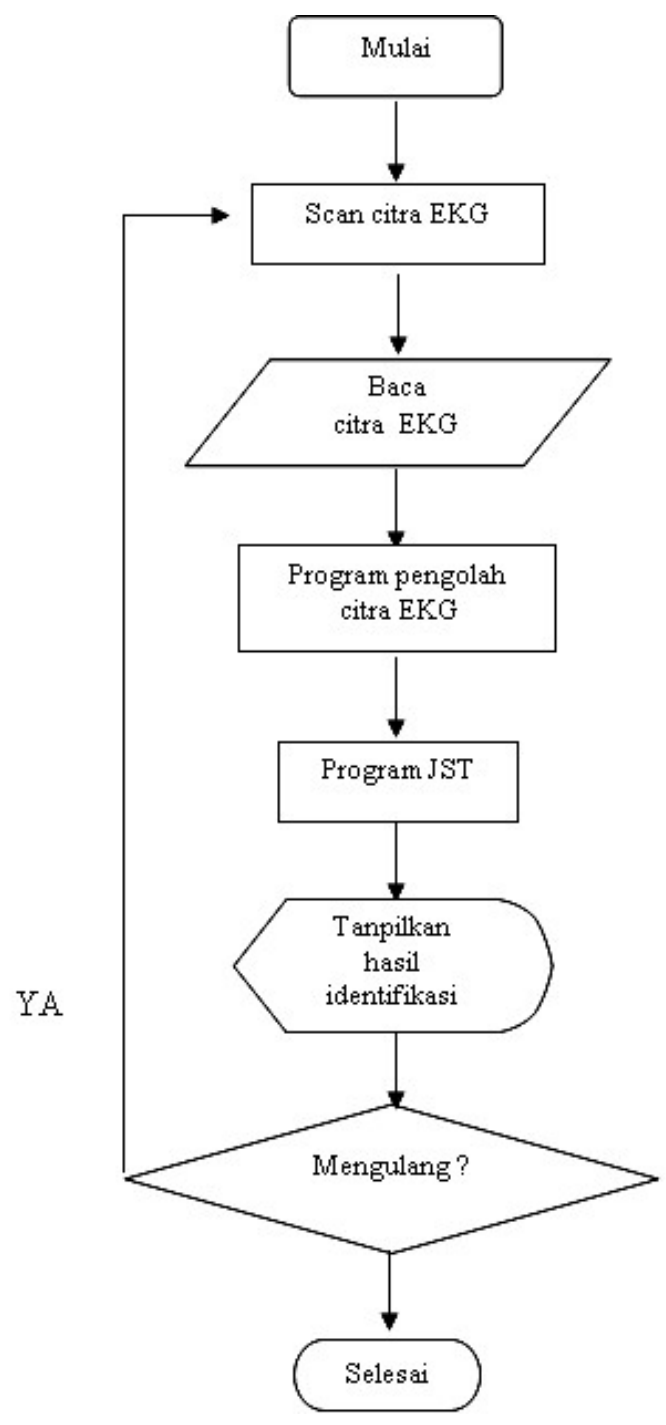

Gambar 8: Diagram alir program utama

\section{B. Jaringan Syaraf Tiruan}

Perancangan JST didasarkan pada algoritma pelatihan sederhana dengan tiga lapisan, yaitu satu lapisan input, satu lapisan hidden, dan satu laipisan output. Penulis sengaja mendesain arsitekturnya sesederhana mungkin dengan maksud untuk mengurangi kekomplekan dalam perhitungan matematis yang dilakukan komputer. JST merupakan metode untuk mencari hubungan antara nilai input dan output melalui serangkaian perhitungan matematis dalam pencapaiannya. Selama ini kita menggunakan regeresi linear (persamaannya $\mathrm{y}=\mathrm{mx}+\mathrm{c}$ ) untuk mencari hubungan antara input dan output. Tetapi untuk kasus-kasus tertentu seperti yang dihadapi penulis di mana input yang digunakan sangat banyak (100) dan hubungan perubahan input terhadap perubahan output tidak linier, maka regresi linear tidak bisa digunakan. Salah satu solusinya adalah dengan menggunakan metode JST [10, 11, 14].

Pada program JST Tabsheet Training, jumlah input dan output JST tidak bisa diubah oleh pengguna, masing-masing ber- 


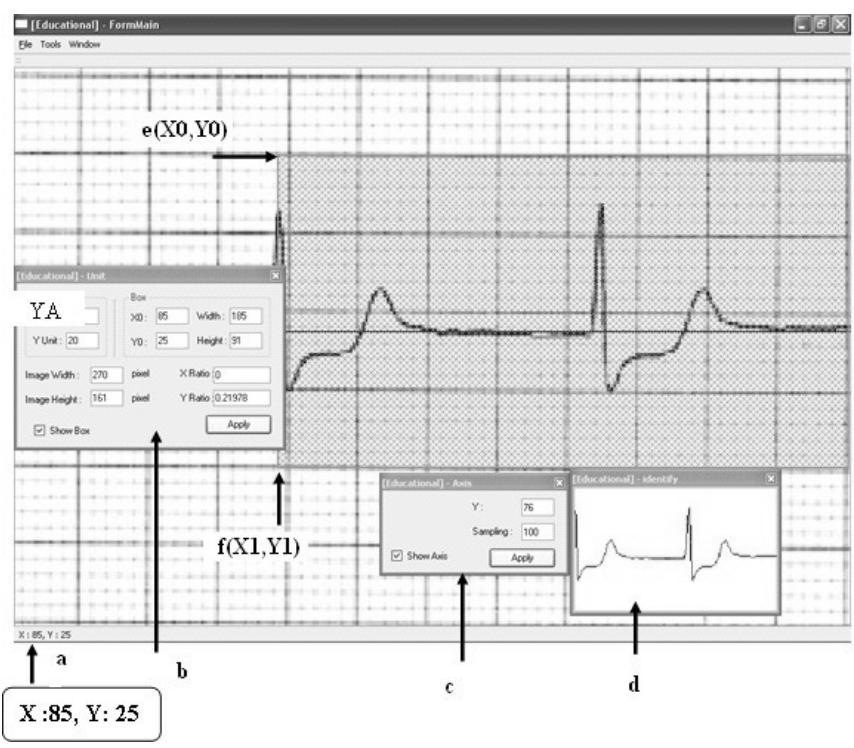

Gambar 9: Form pengolahan citra EKG. a). Koordinat piksel, b). Form Unit, c). Form Axis, d). Form Identify menampilkan hasil pembacaan grafik, e). Koordinat pojok kiri atas sampel, f). Koordinat pojok kiri bawah sampel

\begin{tabular}{|r|r|r|r|r|r|r|r|r|r|}
\hline 8 & 7 & -3 & -4 & -3 & -3 & -2 & -2 & -2 & -2 \\
\hline-1 & -1 & -1 & -1 & -1 & -1 & -1 & -1 & -1 & -1 \\
\hline-1 & -1 & -1 & -1 & -1 & 0 & 0 & 1 & 1 & 2 \\
\hline 2 & 3 & 3 & 3 & 3 & 2 & 2 & 2 & 1 & 1 \\
\hline 1 & 1 & 0 & 0 & 0 & 0 & 0 & 0 & 0 & 0 \\
\hline 0 & 0 & 0 & 0 & 0 & 0 & 0 & 0 & 0 & 0 \\
\hline 0 & 0 & 0 & 0 & 0 & 0 & 0 & 0 & 0 & 0 \\
\hline 0 & 0 & 0 & 0 & 0 & 0 & 0 & 0 & 0 & 0 \\
\hline 0 & 0 & 0 & 0 & 0 & 0 & 0 & 0 & 0 & 0 \\
\hline 0 & 0 & 0 & 0 & 0 & 0 & 0 & 0 & 0 & 0 \\
\hline
\end{tabular}

Gambar 10: Seratus data hasil program pengolah citra EKG

jumlah seratus (100) dan satu (1). Sedangkan jumlah hidden dapat diubah-ubah mulai dari satu (1) sampai lima ratus (500) yang memungkinkan pengguna dapat melihat pengaruh jumlah hidden terhadap kinerja jaringan. Program JST tabsheet Training dapat dilihat pada Gambar 11.

Pengaruh perubahan jumlah hidden terhadap jumlah epoch dan MSE ditampilkan pada Tabel 1. Tabel di atas diperoleh dengan menggunakan parameter-parameter jaringan sebagai berikut:

- Input Training = iskemia depresi ST

- Learning rate $=0,1$

- Maksimum epoch $=5000$

- Target error $=0,01$

Tabel 1. menunjukkan bahwa :

- Semakin besar jumlah hidden, semakin besar jumlah epoch yang berarti proses trainingnya semakin lama.

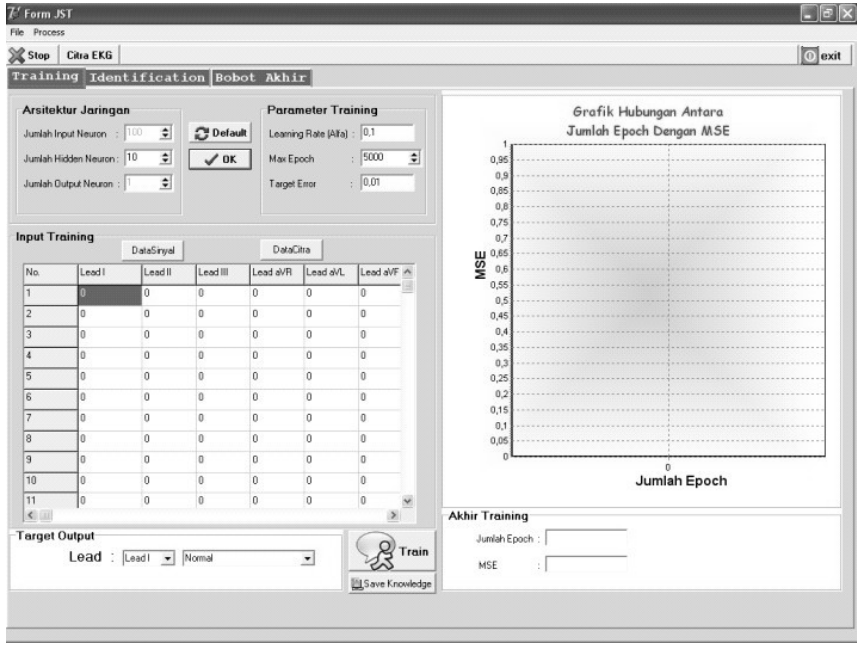

Gambar 11: Tampilan program JST tabsheet Training

Tabel 1 Pengaruh perubahan jumlah hidden
terhadap jumlah epoch dan MSE
\begin{tabular}{|c|c|c|}
\hline Jumlah Hidden & Jumlah Epoch & MSE \\
\hline 2 & 176 & 0,00999 \\
\hline 5 & 1154 & 0,00999 \\
\hline 10 & 1364 & 0,00999 \\
\hline 15 & 5000 & 0,1599 \\
\hline 20 & 5000 & 0,08851 \\
\hline 25 & 5000 & 0,15999 \\
\hline 35 & 5000 & 0,15999 \\
\hline
\end{tabular}

- Jumlah hidden lebih besar dari sepuluh akan mengakibatkan jaringan sulit mencapai kekonvergenan, terlihat pada nilai MSE yang jauh dari target error.

- Proses training berlangsung cepat bila jumlah hidden lebih kecil dari sepuluh, tetapi JST tidak stabil.

Dari beberapa alasan di atas, maka penulis menggunakan sepuluh (10) hidden untuk arsitektur JST.

Pada proses training diperlukan tujuh output, enam untuk kelainan jantung koroner dan satu untuk kondisi jantung yang lain. Karena lapisan output JST hanya memiliki satu neuron, maka penulis menggunakan fungsi aktivasi sigmoid bipolar yang memiliki rentang output (-1 sampai 1) yang lebih lebar dari pada fungsi aktivasi sigmoid biner (0 sampai 1). Selanjutnya rentang output dibagi menjadi tujuh bagian yang masing-masing mewakili kondisi jantung tertentu. Berikut ini adalah target output untuk beberapa kondisi jantung :

- Kondisi jantung normal memiliki target output 0,875

- Kondisi jantung iskemia depresi ST memiliki target output 0,6

- Kondisi jantung iskemia inversi T memiliki target output 0,3

- Kondisi jantung iskemia inversi U memiliki target output 0

- Kondisi jantung injuri memiliki target output -0,3 
- Kondisi jantung nekrosis Q patologis memiliki target output $-0,6$

- Tidak dikenal memiliki target output $-0,875$

Proses training dimulai dengan membaca data input, bobot awal, parameter training (learning rate, maksimum epoch, target error), dan target output. Kemudian dilanjutkan dengan proses feedforward dan backpropagation. Proses feedforward dimulai dari pembacaan bobot awal dan pembacaan nilai input yang diteruskan ke lapisan hidden hingga sampai pada lapisan output kemudian diaktivasi oleh fungsi sigmoid bipolar sehingga dihasilkan nilai output. Misalnya didapat nilai output kondisi jantung injuri adalah - 0,2 sedangkan target outputnya $-0,3$ dan target errornya 0,01 maka nilai errornya adalah $-0,1$ (error $=-0,3-(-0,2)=-0,1)$. Karena nilai error masih lebih besar dari terget error, maka proses feedforward dilanjutkan ke proses backpropagation. Proses ini bertujuan untuk memperkecil nilai error dengan memperbaiki nilai bobot pada setiap lapisan. Proses feedforward dan backpropagation berlangsung berulang-ulang hingga tercapai tujuan training, yaitu jumlah epoch (jumlah perulangan proses feedforward dan backpropagation) lebih besar atau sama dengan maksimum epoch, atau nilai MSE lebih kecil atau sama dengan target error $[1,2]$.

Berikut ini adalah hasil training untuk beberapa kondisi jantung untuk satu lead.

1. Kondisi jantung normal (Gambar 12)

Akhir training :

Jumlah epoch $=2236$

MSE $=0,00999$

Waktu $=33,87$ detik

2. Kondisi jantung iskemia depresi ST (Gambar 13)

Akhir training :

Jumlah epoch $=1092$

$\mathrm{MSE}=0,00999$

Waktu $=16,54$ detik

3. Kondisi jantung iskemia inversi $\mathrm{T}$ (Gambar 14)

Akhir training :

Jumlah epoch $=796$

MSE $=0,00999$

Waktu $=12,06$ detik

4. Kondisi jantung iskemia inversi U

Pada kondisi ini, penulis tidak bisa melakukan training karena tidak ada data tentang kondisi ini. Kenyataanya pada diagnosis EKG sulit untuk mendapatkan gelombang U.

5. Kondisi jantung injuri elevasi ST (Gambar 15)

Akhir training :

Jumlah epoch $=578$

MSE $=0,00999$

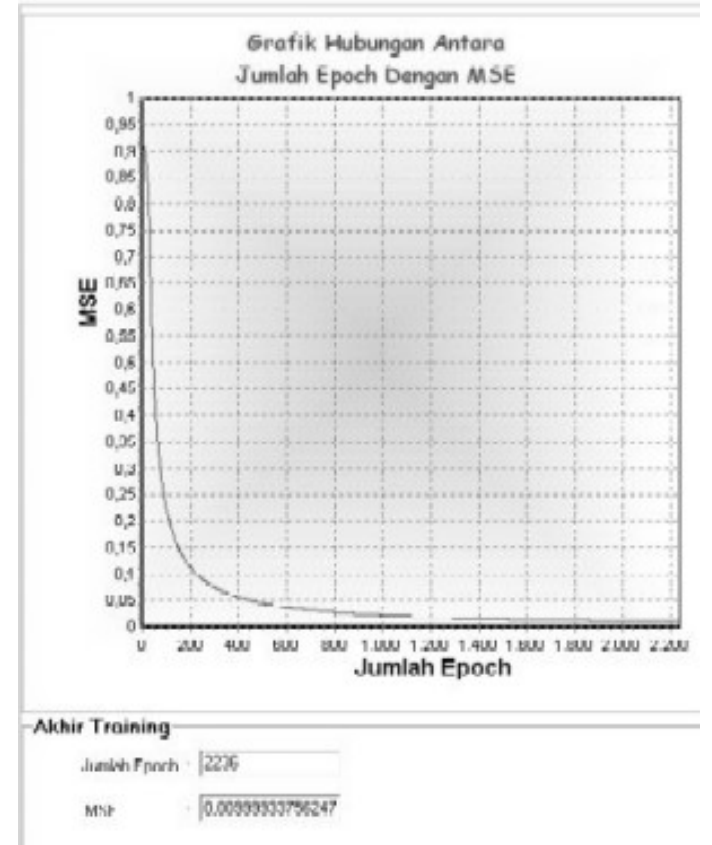

Gambar 12: Hasil training kondisi jantung normal

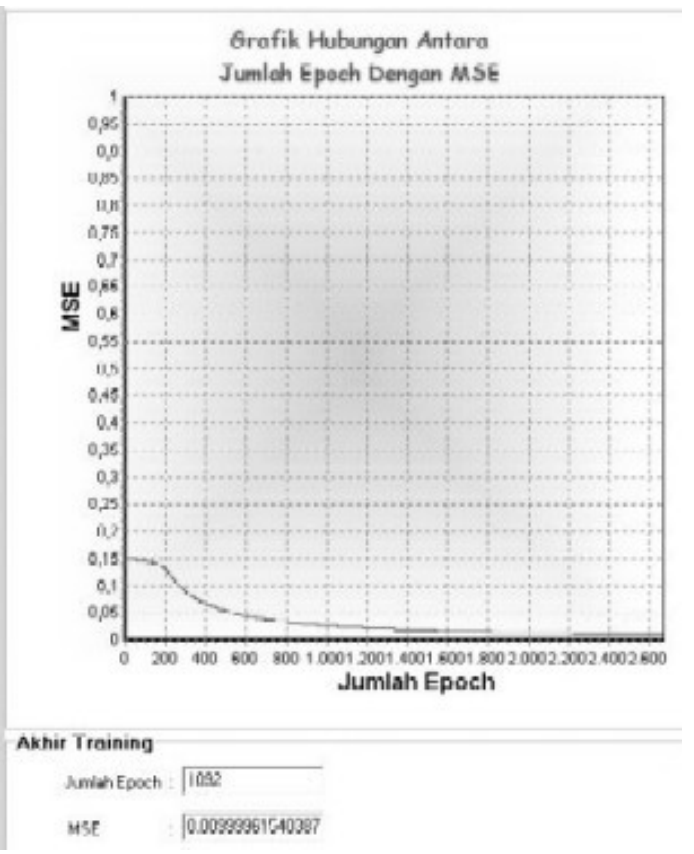

Gambar 13: Hasil training kondisi jantung iskemia depresi ST

Waktu $=8,75$ detik

6. Kondisi jantung nekrosis Q patologis (Gambar 16)

Akhir training :

Jumlah epoch $=298$

MSE $=0,00998$

Waktu $=4,51$ detik 


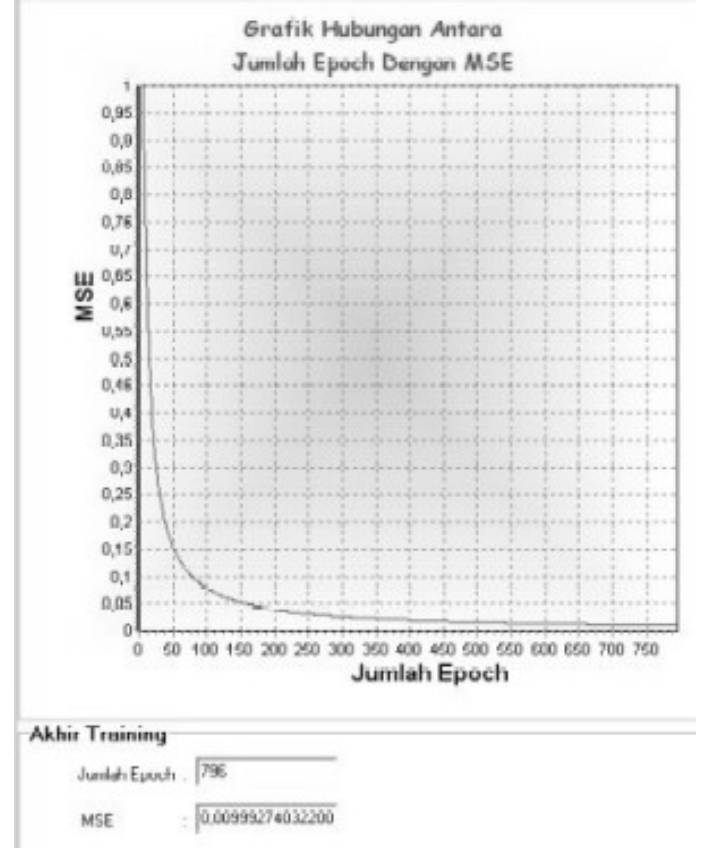

Gambar 14: Hasil training kondisi jantung iskemia inversi $\mathrm{T}$

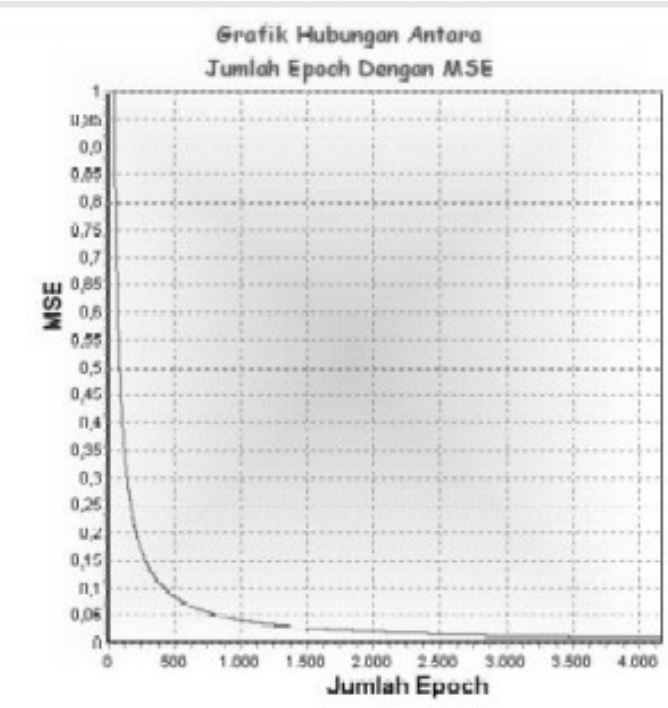

Akhir Training

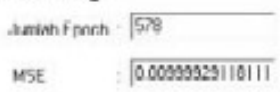

Gambar 15: Hasil training kondisi jantung injuri elevasi ST

7. Tidak dikenal (Gambar 17)

Akhir training :

Jumlah epoch $=4954$

MSE $=0,01023$

Waktu $=75,06$ detik

Proses training dilakukan dengan menggunakan komputer dengan spesifikasi:Prossesor AMD Sempron (tm) 2500+, Me-

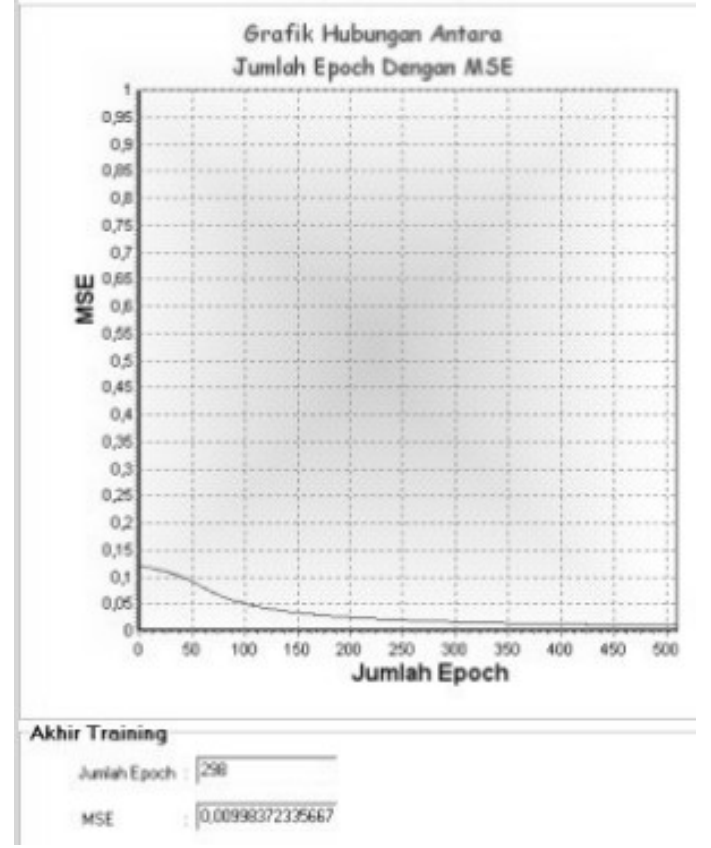

Gambar 16: Hasil training kondisi jantung nekrosis Q patologis

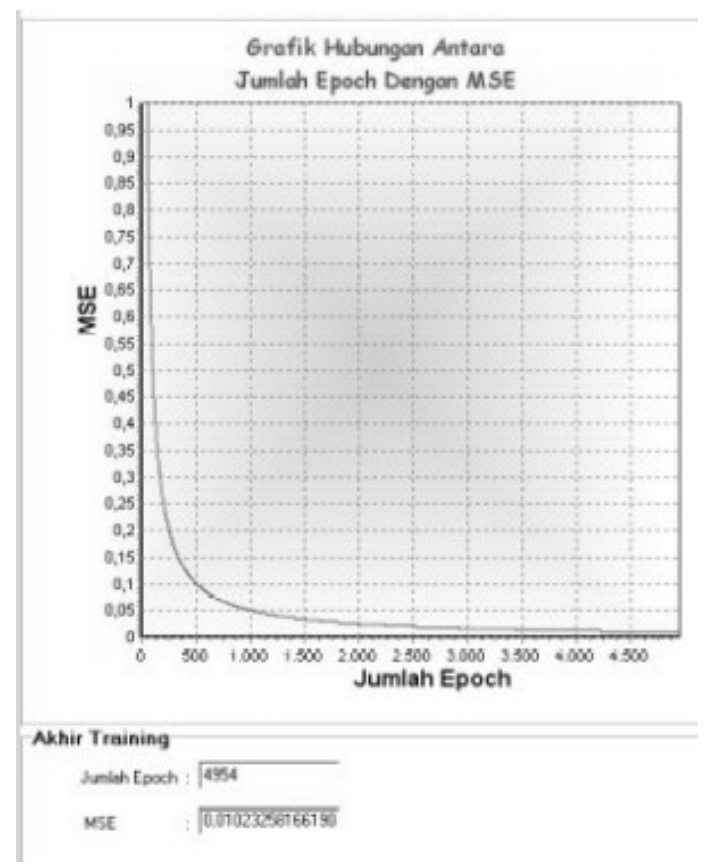

Gambar 17: Hasil training kondisi selain jantung koroner

mori $256 \mathrm{MB}$, Menggunakan OS Microsoft Windows XP Profesional Version 2002 Service Pack 2.

Jika pada training berlangsung proses feedforward dan backpropagation, maka pada identifikasi hanya berlangsung proses feedforward. Feedforward training dengan feedforward identifikasi berbeda hanya pada penggunaan bobot. Bobot yang digunakan untuk training adalah bobot acak, sedangkan bobot yang digunakan pada identifikasi adalah bobot 
akhir hasil training.

\section{SIMPULAN}

Dari hasil penelitian ini, dapat simpulkan bahwa :

1. Operasi titik (operasi pointwise) berdasarkan intensitas piksel dapat diterapkan untuk mengolah citra EKG.

2. Jaringan syaraf tiruan yang telah dibangun memiliki konfigurasi optimal 100-10-1 (100 neuron pada lapisan input, 10 neuron pada lapisan hidden dan 1 neuron pada lapisan output) di mana parameter trainingnya adalah learning rate $=0.1$, maksimum epoch $=5000$ dan target error $=0.01$.

3. Jaringan syaraf tiruan mampu mengidentifikasi kondisi jantung normal, iskemia depresi ST, iskemia inversi T, injuri elevasi T, dan nekrosis Q patologis.
[1] B.Maliawan, Perancangan Dan Pembuatan Elektrokardiograf Yang Dilengkapi Dengan Program Jaringan Syaraf Tiruan Untuk Identifikasi $Q$ Patologis Akibat Gangguan Saluran Koroner,Tugas Akhir,ITS Surabaya (2004)

[2] A.A.Wardhana,Jaringan Syaraf Tiruan Untuk Pengenalan Pola Tulisan Tangan Menggunakan Metode Backpropagation Dengan Fungsi Aktifasi Sigmoid,Tugas Akhir,ITS Surabaya (2004)

[3] http://www.pjnhk.go.id/ [diakses tanggal 25 april 2006]

[4] http://www.depkes.go.id/index.php [diakses tanggal 25 april 2006]

[5] B.Achmad dan K.Firdausy, Teknik Pengolahan Citra Digital Menggunakan Delphi,Ardi Publishing,Yogyakarta (2005)

[6] U. Ahmad, Usman, Pengolahan Citra Digital dan Teknik Pemrogramannya, Graha Ilmu, Bogor (2005)

[7] AC.Guyton, Fisiologi Manusia dan Mekanisme Penyakit,Alih bahasa: Petrus Andrianto,Penerbit Buku Kedokteran EGC,Jakarta (1995)

[8] S.Pratanu, Kursus Elektrokardiografi,PT. Karya Pembina Swajaya, Surabaya (2004)

[9] W.Zimmerman, Classification Of ECG ST Events As Ischemic or Non-Ischemic Using Reconstructed Phase Spaces,Faculty of the Graduate School, Marquette University, wisconsin. Thesis
(2004)

[10] S.Kusumadewi,Artificial Intelligence (Teknik dan Aplikasinya), Graha Ilmu, Yogyakarta (2003)

[11] S.Kusumadewi,Membangun Jaringan Syaraf Tiruan Menggunakan Matlab dan Excel Link,Graha Ilmu, Yogyakarta (2004)

[12] L. Fausett,Fundamental of Neural Networks: Architectures, Algorithms, and Applications,Prentice Hal Inc., USA (1994)

[13] R.Munir, Pengolahan Citra Digital Dengan Pendekatan Algoritmik,Informatika Bandung (2004)

[14] D.E.Rumelhart,Lerning Internal Representations by Error Propagation, Parallel Distributed Processing. Cambridge: MIT Press (1986)

[15] http://id.wikipedia.org/wiki/Jantung [diakses tanggal 25 april 2006]

[16] http://id.inaheart.or.id [diakses tanggal 25 april 2006]

[17] http://www.reindo.co.id/reinfokus/edisi23/jantung koroner.htm [diakses tanggal 25 april 2006]

[18] http://kidshealth.org/kid/body/heart ${ }_{n}$ oSW.html [diakses tanggal 25 april 2006]

[19] http://www.e-dukasi.net/download.php [diakses tanggal 20 april 2006] 